\title{
Comparison Neutrophil to Lymphocyte Count Ratio with C-Reactive Protein as a Predictor for Neonatal Sepsis
}

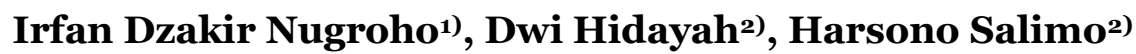 \\ ${ }^{1)}$ Masters Program in Family Medicine, Universitas Sebelas Maret \\ 2)Department of Pediatrics, Dr. Moewardi Hospital, Surakarta
}

\section{ABSTRACT}

Background: Accurate early detection of bacteriemia plays an important role in the treatment and prognosis of infected neonates, but is constrained by the limitations of specific sepsis markers for detecting bacteriemia. NLCR or neutrophil to lymphocyte count ratio in adult population shows a more sensitive parameter in predicting infection and has the advantage of being economical and widely available. The role of NLCR in the neonatal population has not been widely studied. The purpose of this study was to analyze NLCR versus CRP as a predictor of neonatal sepsis.

Subjects and Method: This study take analytic observatinal with diagnostic test approach to subject with sepsis risk factor and neonatal sepsis at dr. Moewardi hospital from April until May 2017. Characteristics data as gestational age, gender, birth weight, IT ratio, leucocyte count, neutrophil and lymphocyte count, NLCR, CRP and blood culture. Data presented descriptively and statistical analysis was performed.
Results: No significant correlation between subject's characteristics and neonatal sepsis. NLCR with cutoff point for 2.22 has sensitivity, specificity, positive and negative predictive value for $87.5 \%, 75 \%, 70 \%$ and $90 \%$, respectively. CRP with cutoff point for 0.25 has sensitivity, specificity, positive and negative predictive value for $83.3 \%, 55.6 \%, 55.6 \%$ and $83.3 \%$ respectively. While IT-rasio has sensitivity, specificity, positive and negative predictive value for $29.2 \%, 91.7 \%, 70 \%$ and $66 \%$, respectively.

Conclusion: NLCR has a satisfactory predictive value for neonatal sepsis that widely available and economic predictor alternative with cutoff point for 2.22 .

Keywords: NLCR, CRP, predictor, neonatal sepsis

\section{Correspondence:}

Irfan Dzakir Nugroho. Masters Program in Family Medicine, Universitas Sebelas Maret. Jl. Ir. Sutami 36A, Surakarta, Central Java.

Cite this as:

Nugroho ID, Hidayah D, Salimo H (2021). Comparison Neutrophil to Lymphocyte Count Ratio with CReactive Protein as a Predictor for Neonatal Sepsis. Indones J Med. 06(02): 135-144. https://doi.org/10.26911/theijmed.2021.06.02.02.

cc (i) (2) Indonesian Journal of Medicine is licensed under a Creative Commons (c) $\mathrm{EY}$ NC SA Attribution-NonCommercial-ShareAlike 4.0 International License.

\section{BACKGROUND}

In newborns, infection that progresses to sepsis is a clinical symptom of systemic disease accompanied by bacteriemia occurring in the early months of life (Gomella et al., 2013). In developing countries, nearly the majority of inpatient newborns have sepsis-related morbidity and mortality. The incidence of sepsis is still quite high in developing countries when compared to developed countries (Gerdes, 2004). The risk of sepsis is increased in preterm infants and infants with low birth weight when compared to term infants with moderate body weight (Aminullah, 2010; Pusponegoro, 2000; Stoll and Shane, 2016).

Accurate early detection of bacteriemia plays an important role in treatment and patient prognosis. Sepsis markers such as leukocyte count, absolute neutrophil 
count (ANC) and C-reactive protein (CRP) are well known markers for detecting bacteriemia. However, these markers cannot precisely distinguish between infections caused by bacteria, fungi or severe viral infections. Additional infection markers such as procalcitonin (PCT) can predict bacteriemia accurately but are constrained by availability and relatively high cost (Auriti et al., 2012; da Silva et al., 1995; de Jager et al., 2010; Holub et al., 2012; Rruntunuwu et al., 2008).

In infections caused by bacteria, physiological immunity will respond, one of which is by increasing the value of nephrophils and decreasing the value of lymphocytes. The phenomenon of absolute lymphocytopenia to immune response in systemic infections is not well understood but neutrophilia and lymphocytopenia in recent studies combined with other markers of infection have shown good results in predicting bacteriemia. This suggests the role of neutrophils and lymphocytes in detecting the early stages of the immune response against bacteriemia. The ratio of neutrophil to lymphocyte count or neutrophil to lymphocyte count ratio (NLCR) in the adult population shows a more sensitive parameter than the leukocyte count in predicting infection and has the advantage of being inexpensive and widely available when compared to other markers. NLCR in the neonatal population has not been widely studied.

This study aims to analyze the value of NLCR compared to CRP as a predictor of neonatal sepsis, to analyze the NLCR and CRP cutoff points and to analyze the sensitivity, specificity, positive predictive value, negative predictive value, and accuracy of NLCR and CRP as predictors of neonatal sepsis.

\section{SUBJECTS AND METHOD \\ 1. Study design}

This was an analytic observational study with a diagnostic test approach. The study was conducted at the Regional General Hospital (RSUD) Dr. Moewardi, Surakarta.

\section{Study sample}

Infants treated in the neonatal HCU room and the NICU at dr. Moewardi Surakarta between April 2018 and May 2018 was selected for this study by consecutive sampling. The inclusion criteria were all patients with potential infection or had clinical neonatal sepsis while the exclusion criteria were parents with acquaired immunondeficiency syndrome (AIDS), surgery, history of previous antibiotics, major congenital anomalies, severe the body is born less than 1000 grams.

\section{Definition operational of variables}

Infected neonatal was defined as a newborn with risk factors for sepsis in which condition it is predicted that infection has occurred but has not shown neonatal sepsis. These risk factors are labor with action, premature rupture of membranes for more than 18 hours, intrapartum infection, chorioamnionitis, fever in mothers with a temperature of more than $38.4^{\circ} \mathrm{C}$, perinatal asphyxia, prematurity and low birth weight (Gomella et al., 2013; Aminullah, 2010).

Meanwhile, neonatal sepsis is based on finding at least 2 clinical signs and 2 laboratory signs from the following criteria, namely systolic blood pressure less than 40 $\mathrm{mmHg}$, heart rate less than 50 or more than 220 times per minute, cardiac arrest occurs, poor perfusion, cyanosis or mottling, $\mathrm{pH}$ blood less than 7.2 at normal $\mathrm{PaCO} 2$, need for inotropic agents to maintain blood pressure or cardiac output, respiratory rate more than 90 times per minute, $\mathrm{PaCO} 2$ more than $65 \mathrm{mmHg}, \mathrm{PaO} 2$ less 
than $40 \mathrm{mmHg}$, require mechanical ventilation, oxygen fraction less than 200 without abnormality cyanotic heart, hemoglobin below $5 \mathrm{~g} / \mathrm{dl}$, leukocyte count less than 9000 cells / mm3, platelet count less than 150,00o cells/ $\mathrm{mm}^{3}$, decreased consciousness with pupil dilatation, lethargy, irritability more than $100 \mathrm{mg} / \mathrm{dL}$ or plasma creatinine more than $20 \mathrm{mg} / \mathrm{dL}$, gastrointestinal bleeding accompanied by decreased hemoglobin more than $2 \mathrm{~g} / \mathrm{dL}$ in 24 hours, need for blood transfusion, hypotension with blood pressure less than the 3rd percentile for age and gastrointestinal surgery, intake intolerance, diarrhea, abdominal distension, total bilirubin more than $3 \mathrm{mg} / \mathrm{dL}$ and jaundice, hypoglycemia, hyperglycemia and metabolic acidosis (Gomella et al., 2013; Gerdes, 2004).

Based on the results of blood culture, all subjects were classified into 2 groups, namely the group of infected neonates who developed confirmed sepsis with positive culture results, hereinafter referred to as the culture-confirmed group of sepsis and the group of infected neonates with negative culture results, hereinafter referred to as the infected neonatal group.

\section{Data analysis}

Data analysis using SPSS version 17.0 program. The baseline characteristics of the subjects were described as percentages and these variables were divided into cultureconfirmed sepsis groups and infected neonatal groups then compared and statistical correlation analysis was performed. $P$ value $<0.05$ was considered significant. The optimal intercept will be determined using Microsoft Office Excel by taking the output of the Coordinates of the Curve from the ROC. The cut point data for NLCR and CRP and IT-ratio with cut point 0.2 were tabulated and entered into a 2x2 table of blood culture results and calculations were performed to find sensitivity, specificity, positive predictive value, negative predictive value, positive likelihood ratio, ratio negative possibilities and accuracy. Diagnostic ability is considered good when the diagnostic parameters $>80 \%$ (Dahlan, 2009).

\section{Research ethics}

The data recorded were patient identity, gender, maternal age, history of premature rupture of membranes (PROM) more than 18 hours, chorioamnionitis, birth weight, results of routine blood tests, leukocyte count, IT-ratio, NLCR, CRP and blood culture examination. This research was conducted with the approval of the Ethics Committee of RSUD Dr. Moewardi Surakarta.

\section{RESULTS}

Of the total 60 study subjects, divided into 2 groups, namely the culture-confirmed sepsis group, 24 subjects (40\%) and the unconfirmed culture group, called neonatal infected, were 36 subjects (60\%). Then the characteristics of the study subjects such as gender, gestational age, history of PROM, chorioamnionitis, birth weight, leukocytes and platelets are demographed in Table 1.

In a diagnostic test, the optimal intersection point for NLCR and CRP will be determined using Microsoft Office Excel by taking the output of the Coordinates of the Curve from the ROC. The results of this study were 24 patients with positive cultures and 36 patients with negative cultures. Based on these results, which are compared with the results of NLCR and CRP measurements, the results of the ROC curve and the optimal intersection point are obtained in Figure 1. 
Table 1. Sample characteristics

\begin{tabular}{|c|c|c|c|}
\hline \multirow{2}{*}{ Characteristics } & \multicolumn{2}{|c|}{ Blood culture } & \multirow{2}{*}{$\mathbf{p}$} \\
\hline & Positive $(n=24)$ & Negative $(n=36)$ & \\
\hline \multicolumn{4}{|l|}{ Sex } \\
\hline Female & 8 & 14 & 0.662 \\
\hline Male & 16 & 22 & \\
\hline \multicolumn{4}{|l|}{ Gestational age } \\
\hline$<37$ weeks & 16 & 22 & 0.662 \\
\hline$\geq 37$ weeks & 8 & 14 & \\
\hline \multicolumn{4}{|c|}{$\begin{array}{l}\text { History of premature rupture } \\
\text { membrane }\end{array}$} \\
\hline Positive & 8 & 15 & 0.515 \\
\hline Negative & 16 & 21 & \\
\hline \multicolumn{4}{|l|}{ Chorioamniotic } \\
\hline Positive & 8 & 11 & 0.821 \\
\hline Negative & 16 & 25 & \\
\hline \multicolumn{4}{|l|}{ Low birth weight } \\
\hline Severe low birth weight & 6 & 9 & 0.888 \\
\hline Low birth weight & 10 & 13 & \\
\hline Normal birth weight & 8 & 14 & \\
\hline \multicolumn{4}{|l|}{ Leukocyte } \\
\hline Leukopenia & 6 & 7 & 0.167 \\
\hline Normal & 16 & 29 & \\
\hline Leukocytosis & 2 & 0 & \\
\hline \multicolumn{4}{|l|}{ Thrombocyte } \\
\hline Thrombocytopenia & 7 & 8 & 0.543 \\
\hline Normal & 17 & 28 & \\
\hline
\end{tabular}

Based on the ROC curve, the AUC value for NLCR was 0.876 with a value of $\mathrm{p}<0.001$. The cutoff value with the best sensitivity and specificity for NLCR was 2.215, namely at Sensitivity $=0.88$ and 1Specificity $=0.25$. As for $\mathrm{CRP}$, the $\mathrm{AUC}=$ 0.73 with $\mathrm{p}=0.003$. The cut off value with the best sensitivity and specificity for CRP was 0.25 , namely at Sensitivity= 0.83 and 1-Specificity $=0.44$. This results are shown in Table 2.

Based on the cutoff value on the ROC curve, the NLCR is divided into 2 categories for screening purposes, namely NLCR $>2.22$ and $<2.22$. Thus, the results of cross tabulation were obtained with the following blood culture results.

Based on the cutoff value on the ROC curve, the NLCR is divided into 2 categories for screening purposes, namely NLCR $>2.22$ and $<2.22$. Thus, the results of cross tabulation with blood culture results are obtained in Table 3.

Based on the results of cross tabulation of NLCR with blood culture, a diagnostic analysis was performed with the results as shown in Table 4.

Examination of neonatal sepsis with NLCR at the cutoff point of 2.22 resulted in a sensitivity of $87.5 \%$, a specificity value of $75 \%$, a positive predictive value (NDP) of $70 \%$, a negative predictive value (NDN) of 90\%. The positive likelihood ratio (RKP) was 3.25 , the negative likelihood ratio (RKN) was 0.167 .

Based on the cutoff value on the ROC curve, the CRP is divided into 2 categories for screening purposes, namely with NLCR 
Nugroho et al./ Comparison Neutrophil to Lymphocyte Count Ratio with C-Reactive Protein

$>0.25$ and $<0.25$. Thus, the results of cross

obtained in table 5 .

tabulation with blood culture results are

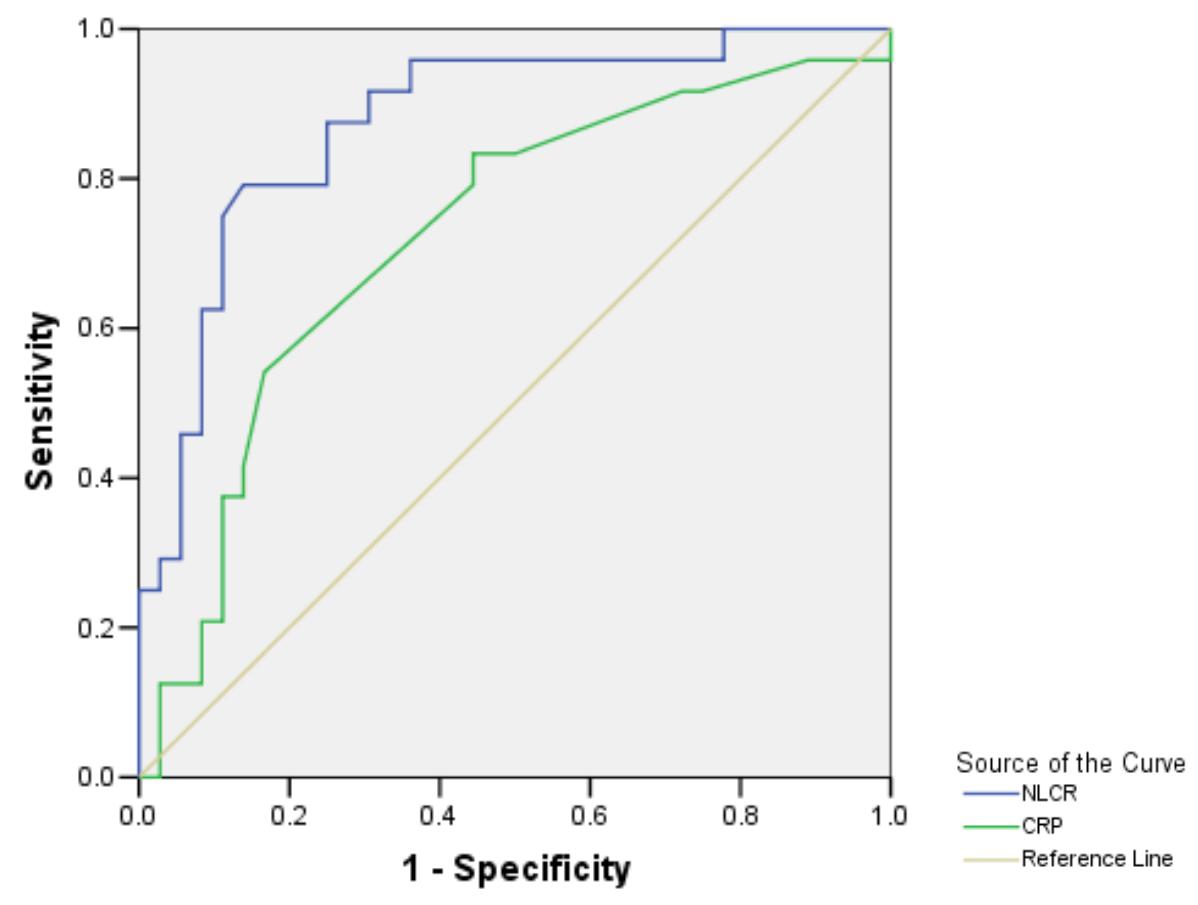

Figure 1. ROC curve

Table 2. Results of determining the intersection of the NLCR and CRP

\begin{tabular}{lccccc}
\hline \multicolumn{1}{c}{ Variables } & AUC & Sensitivity & Sensitivity & Cutoff & p \\
\hline NLCR & 0.88 & 0.88 & 0.25 & 2.22 & $<0.001$ \\
CRP & 0.73 & 0.83 & 0.44 & 0.25 & 0.003 \\
\hline
\end{tabular}

Table 3. Cross-tabulation of NLCR with blood cultures

\begin{tabular}{cccc}
\hline \multirow{2}{*}{ NLCR } & \multicolumn{2}{c}{ Blood Culture } & \multirow{2}{*}{ Total } \\
\cline { 2 - 3 } & Positive & Negative & \\
\hline 2.22 & 21 & 9 & 30 \\
$<2.22$ & 3 & 27 & 30 \\
Total & 24 & 36 & 60 \\
\hline
\end{tabular}

Table 4. Diagnostic test results

\begin{tabular}{lccc}
\hline & NLCR & CRP & IT-ratio \\
\hline Sensitivity & $87.5 \%$ & $83.3 \%$ & $29.2 \%$ \\
Specificity & $75 \%$ & $55.6 \%$ & $91.7 \%$ \\
NDP & $70 \%$ & $55.6 \%$ & $70 \%$ \\
NDN & $90 \%$ & $83.3 \%$ & $66 \%$ \\
RKP & 3.25 & 1.88 & 3.5 \\
RKN & 0.17 & 0.3 & 0.77 \\
\hline
\end{tabular}

Table 5. Cross-tabulation of CRP with blood cultures

\begin{tabular}{lcccc} 
& \multirow{2}{*}{ CRP } & \multicolumn{2}{c}{ Blood Culture } & \multirow{2}{*}{ Total } \\
\cline { 2 - 3 } & Positive & Negative & \\
\hline$>0.25$ & 20 & 16 & 36 \\
$<0.25$ & 4 & 20 & 24
\end{tabular}


Nugroho et al./ Comparison Neutrophil to Lymphocyte Count Ratio with C-Reactive Protein

Total

24

36

60

Based on the results of cross tabulation of CRP with blood culture, a diagnostic analysis was performed with the results as shown in Table 4.

Examination of neonatal sepsis with CRP at the cutoff point of 0.25 obtained a sensitivity of $83.3 \%$, the specificity value of CRP was $55.6 \%$, NDP was $55.6 \%$, NDN was
83.3\%. The RKP value was 1.875 , the RKN value was 0.3

Whereas in the diagnostic test results $\mathrm{I} / \mathrm{T}$ the ratio based on the cutoff value $\mathrm{I} / \mathrm{T}$ ratio is divided into 2 categories, namely the $\mathrm{I} / \mathrm{T}$ ratio $>0.2$ and $<0.2$ where with the fisher exact test the value of $p=0.073$ was obtained. cross tabulation with neonatal sepsis in table 6.

Table 6. Cross-tabulation of I / T ratios with blood cultures

\begin{tabular}{cccc}
\hline \multirow{2}{*}{ I/T ratio } & \multicolumn{2}{c}{ Blood Culture } & \multirow{2}{*}{ Total } \\
\cline { 2 - 3 } & Positive & Negative & 10 \\
$>0.2$ & 7 & 3 & 50 \\
$<0.2$ & 17 & 33 & 60 \\
Total & 24 & 36 & \\
\hline
\end{tabular}

Based on the results of cross tabulation of I/T ratio with blood culture, a diagnostic analysis was performed with the results as shown in table 4.

Examination of neonatal sepsis with $\mathrm{I} / \mathrm{T}$ ratio at the cut point of 0.2 obtained a sensitivity of $29.2 \%$, specificity of $91.7 \%$, NDP of $70 \%$, NDN of $66 \%$, RKP value of 3.5 , and $\mathrm{RKN}$ value of 0.773 .

\section{DISCUSSION}

Early diagnosis of neonatal sepsis has an important role in which delay or delay can determine the prognosis. The diagnosis of sepsis in newborns is difficult to establish when compared to older children because the clinical features of sepsis in newborns are not specific. The clinical picture of sepsis in newborns is not much different from non-infectious diseases that have severe morbidity in newborns. In addition, the absence of investigations can serve as the sole definitive examination in the diagnosis of sepsis (Gomella et al., 2013; Aminullah, 2010).

The gold standard diagnosis in neonatal sepsis is blood culture, but this test has drawbacks such as the test results taking 2 to 5 days to show results. From the research, it was found that a minimum of 1 $\mathrm{ml}$ of blood was needed for blood culture tests. The number of blood samples less than $1 \mathrm{ml}$ can reduce sensitivity. Although $0.5 \mathrm{ml}$ of blood is reported to be used for blood culture, in vitro data from Schelonka et al. (1996) show that a blood sample of $0.5 \mathrm{ml}$ cannot detect bacteriemia with low blood levels. In addition, as many as $25 \%$ of newborns with sepsis have low bacteriemia levels $(\leq 4 \mathrm{CFU} / \mathrm{ml})$ and two thirds of newborns under 2 months of age have colony levels less than $10 \mathrm{CFU} / \mathrm{ml} .1,3,16,17$ , 18,19 Therefore, it is necessary to have an early marker that has a high diagnostic and predictive value so that it can avoid delaying early treatment administration.

The markers that have been widely used as parameters for bacterial infection are CRP, leucocyte count, procalcitonin and neutrophil count. However, these markers have their respective limitations such as not always giving a picture of infection caused by bacteria, high availability and cost. $8,9,20$ Because of these constraints, reliable 
markers are needed that can provide an overview of bacterial infection and have wide availability and modest costs. The results of routine blood tests have the potential to fill a role as a marker.

Early markers of neonatal sepsis ideally are predictors of infection and sepsis prior to clinical manifestations. According to Zahorec in a study in 2001, NLCR which is characterized by an increase in the number of neutrophils and a decrease in the number of lymphocytes is known to be detected since the first 5 hours of infection, even at that time there are no clinical manifestations of infection in neonates.

Increased neutrophil count and decreased lymphocyte count are well-known markers of severe bacterial infection. However, their use alone cannot be relied on as a marker of bacteriemia. In a 2001 study by Zahorec, it was found that the ratio of the neutrophil to lymphocyte count or the neutrophil to lymphocyte count ratio is a parameter that can show the degree of morbidity of systemic inflammation and other stressful conditions. In this study, it was observed that periodic rapid changes in leukocytes as a response to the immune system to trauma stress, surgery, systemic inflammation and sepsis. The preliminary results of the study showed a correlation between the degree of clinical morbidity with an increase in neutrophil values and a decrease in lymphocyte values. The NLCR in this case is an easy parameter to use to express this morbidity (Holub et al., 2012; Zahorec, 2001; Rainer et al., 1999).

Increased neutrophils show a response to microbial infection and then migrate rapidly to specific sites. At the same time, there is phagocytosis, release of cytokines and activation of $\mathrm{T}$ cells. On the other hand, some anti-inflammatory agents cause margination and redistribution of lymphocytes within the lymphatic system characterized by accelerated apoptosis. A study conducted by Jilma in 1999 that administered lipopolysaccharide substrates as endotoxin to volunteers showed a decrease in lymphocytes up to $85 \%$, a decrease in monocytes up to $96 \%$ and an increase in neutrophils up to $300 \%$ at 4-6 hours after the endotoxin administration (Holub et al., 2012; Zahorec, 2001; Rainer et al., 1999).

Increased neutrophils show a response to microbial infection and then migrate rapidly to specific sites. At the same time, there is phagocytosis, release of cytokines and activation of $\mathrm{T}$ cells. On the other hand, some anti-inflammatory agents cause margination and redistribution of lymphocytes within the lymphatic system characterized by accelerated apoptosis. A study by Jilma in 1999 which gave lipopolysaccharide substrates as endotoxins to volunteers showed a decrease in lymphocytes up to $85 \%$, a decrease in monocytes up to $96 \%$ and an increase in neutrophils up to $300 \%$ at $4-6$ hours after giving these endotoxins (Zahorec, 2001; Jilma et al., 1999; Hwang et al., 2017; Laukemann et al., 2015).

Omran et al. (2017) conducted a study on the value of NLCR in newborns with sepsis and fit newborns. It was found that the NLCR in septic infants had a higher NLCR value than in fit infants. With a cutoff point value of 2.7, it was found that a sensitivity value was $80 \%$ and a specificity value was 57.1\% (Omran et al., 2017).

In this study, NLCR could predict neonatal sepsis with a good diagnostic value. With a cutoff point of 2.22, the NLCR has a sensitivity of $87.5 \%$, which means that $87.5 \%$ of patients with positive cultures can be predicted by NLCR $>2.22$, a specificity of $75 \%$ which means that $75 \%$ of the chances of a patient diagnosis with negative cultures can be ruled out in patients who have a negative culture. NLCR >2.22. An NDP of 
$70 \%$ means that the NLCR if the result is $>2.22$ then there is a $70 \%$ chance that the patient will have a positive culture. 90\% NDN means that the NLCR if the result is $<2.22$ then there is a $90 \%$ chance of the patient with a negative culture. A RKP value of 3.25 means that the probability ratio of patients who have an NLCR $>2.22$ will get a positive culture result of 3.25 times greater than that of patients who have an NLCR <2.22. An RKN value of 0.17 means that the ratio of the likelihood that patients with NLCR $<2.22$ will get a positive culture patient is 0.167 times smaller than that of patients with an NLCR > 2.22.

On the results of CRP, this examination can predict neonatal sepsis with confirmed blood culture with a diagnostic value that is quite good but not better than the NLCR examination. With a cut point of 0.25, the CRP has a sensitivity of $83.3 \%$, which means $83.3 \%$ of patients with positive cultures can be predicted with a CRP $>0.25$, a specificity of $55.6 \%$, which means $55.6 \%$ of the chances of diagnosis of patients with negative cultures can be excluded in patients who have a CRP> 0.25. An NDP of $55.6 \%$ means that if the CRP is $>0.25$, then there is a $55.6 \%$ chance of a positive culture result. NDN $83.3 \%$ means that CRP if the result is $<0.25$ then there is a possibility that $83.3 \%$ of the subjects will have a negative culture. A RKP value of 1.88 means that the likelihood ratio of patients who have CRP >0.25 will have a positive culture result of 1.875 times greater than that of patients who have CRP $<0.25$. An $\mathrm{RKN}$ value of 0.3 means that the ratio of the likelihood that patients with CRP $<0.25$ will have a positive culture result is 0.3 times smaller than that of patients with CRP $>0.25$.

Even when compared with the IT ratio that is routinely used as an early marker of neonatal sepsis, NLCR has a better sensitivity value. This is consistent with the research of Ozdemir et al. (2017) in preterm infants with neonatal sepsis where the cutoff point of the NLCR was 1.71, the sensitivity was $73 \%$ and specificity was $78 \%$ (Ozdemir et al., 2017). These results suggest a good diagnostic NLCR result as an early marker of neonatal sepsis in preterm infants.

Although in this study it was found that the IT ratio had a higher specificity value than NLCR and CRP, in the application of early markers to provide early treatment, the diagnostic value of NLCR and CRP was more important than the I/T ratio. When considering examination costs and availability, the NLCR examination is cheaper and easier than the CRP examination.

The weakness of this study is that the analysis of procalcitonin as a predictor of neonatal sepsis has not been carried out due to the high cost of testing, but the slow onset of procalcitonin value makes this examination less appropriate in patients with fast onset neonatal sepsis.

\section{AUTHOR CONTRIBUTION}

Irfan Dzakir Nugroho, Dwi Hidayah, and Harsono Salimo, collected the data, did data analysis, and wrote the manuscript.

\section{CONFLICT OF INTEREST}

None.

FUNDING AND SPONSORSHIP

There was no external fund.

\section{ACKNOWLEDGEMENT}

We thank to infant's parents in $\mathrm{dr}$. Moewardi hospital, who gave permission to collect their data and information for this study.

\section{REFERENCE}


Nugroho et al./ Comparison Neutrophil to Lymphocyte Count Ratio with C-Reactive Protein

Aminullah A (2010). Sepsis pada bayi baru lahir. Dalam : Kosim MS, Yunanto A, Dewi R, Sarosa GI, Usman A, penyunting. Buku Ajar Neonatologi edisi pertama. Jakarta: Ikatan Dokter Anak Indonesia.

Auriti C, Fiscarelli E, Ronchetti MP, Argentieri M, Marrocco G, et al. (2012). Procalcitonin in detecting neonatal nosocomial sepsis. Arch Dis Child Fetal Neonatal Ed. 97(5): F368-70. https://doi.org/10.1136/fetalneonatal -2010-194100.

Da Silva O, Ohlsson A, Kenyon C (1995). Accuracy of leukocyte indices and Creactive protein for diagnosis of neonatal sepsis: a critical review. Pediatr Infect Dis J. 14(5): 362-6. https://doi.org/10.1097/00006454-19950500000005 .

Dahlan MS (2009). Penelitian diagnostik. Jakarta: Salemba Medika.

de Jager CP, van Wijk PT, Mathoera RB, deJongh-Leuvenink J, van der Poll T, Wever PC (2010). Lymphocytopenia and neutrophil-lymphocyte count ratio predict bacteremia better than conventional infection markers in an emergency care unit. Crit Care. 14(5): R192. https://doi.org/10.1186/cc9309.

Dietzman DE, Fischer GW, Schoenknecht FD (1974). Neonatal Escherichia coli septicemia-bacterial counts in blood. J Pediatr. 85(1): 128-30. https://doi.org/10.1016/s0022-3476(74)80308-

2.

Gerdes JS (2004). Diagnosis and management of bacterial infection in the neonate. Pediat Clin N Am. 51(4): 939-59. https://doi.org/10.1016/j.pcl.2004.03.009.

Gomella TL, Cunningham MD, Eyal FG, Tuttle DJ (2013). Sepsis, Neonatology 25th edition. United States of America: McGraw-Hill Education.

Holub M, Beran O, Kasprikova N, Chalupa $P$ (2012). Neutrophil to lymphocyte count ratio as a biomarker of bacterial infections. Cent Eur J Med. 7(2): 25861. https://doi.org/10.2478/s11536-O12-0002-3.

Hwang SY, Shin TG, Jo IJ, et al. (2017). Neutrophil-to-lymphocyte ratio as a prognostic marker in critically-ill septic patients. Am J Emerg Med. 35(2): 234-9. https://doi.org/10.1016/j.ajem.2016.10.055.

Jilma B, Blann A, Pernerstorfer T, Stohlawetz P, et al. (1999). Regulation of adhesion molecules during human endotoxemia. Amer J Resp Crit Care Med. 159(3): 857-63. https://doi.org/10.1164/ajrccm.159.3.9805087.

Kumar Y, Qunibi M, Neal TJ, Yoxall CW (2001). Time to positivity of neonatal blood cultures. Arch Dis Child Fetal Neonatal. 85(3): F182-6. http://dx.doi.org/10.1136/fn.85.3.F182.

Laukemann S, Kasper N, Kulkarni P, Steiner D, Rast AC, Kutz A, Felder S, Haubitz S, et al. (2015). Can we reduce negative blood cultures with clinical scores and blood markers? Results from an observational cohort study. Medicine (Baltimore). 94(49):e2264. https://doi.org/10.1097/md.oooooo 0000002264 .

Loonen AJM, de Jager CPC, Tosserams J, Kusters R, Hilbink M, WeverPC, van den Brule AJC (2014). Biomarkers and molecular analysis toimprove bloodstream infection diagnostics in an emergency care unit. PLoS One. 9(1): e87315. https://doi.org/10.1371/journal.pone.0o87315.

Omran A, Maaroof A, Saleh MH, Abdelwahab A (2017). Salivary C-reactive protein, mean platelet volume and 
Nugroho et al./ Comparison Neutrophil to Lymphocyte Count Ratio with C-Reactive Protein

neutrophil lymphocyte ratio as diagnostic markers for neonatal sepsis. $\mathrm{J}$ Pediatr (Rio J). 94(1): 82-87. https://doi.org/10.1016/j.jped.2017.03.006.

Ozdemir SA, Ozer EA, Ilhan O, Sutcuoglu S (2017). Can neutrophil to lymphocyte ratio predict late-onset sepsis in preterm infants?. J Clin Lab Anal. 32(4): e22338. https://doi.org/10.1002/jcla.22338 .

Polin RA. 2012. Management of neonates with suspected or proven early-onset bacterial sepsis. American Academy of Pediatrics. 129(5): D1-6.

Pusponegoro TS (2000). Sepsis pada neonatus. Sari Pediatri. 2(2): 96-102. https://dx.doi.org/10.14238/sp2.2.20 00.96-102.

Rahman T, Utomo MT, Etika R, Indarso F, Harianto A, Damanik SM (2007). Sepsis neonatorum di RSU dr. Soetomo Surabaya 2006. Dalam: Sadjimin T, Juffrie M, Julia M, Wibowo T, editor. PIT IKA III IDAI. Yogyakarta: Percetakan KITA.

Rainer TH, Chan TYF, Cocks RA (1999). Do peripheral blood counts have any prognostic value following trauma?. Injury. 30(3): 179-85. https://doi.org/10.1016/soo20-1383(98)00247-2.

Rohsiswatmo R (2005). Kontroversi diagnosis sepsis neonatorum. Dalam: Hegar B, Trihono PP, Ifran EB, editor. Update in neonatal infection. Jakarta: Departemen Ilmu Kesehatan Anak FKUI-RSCM.
Runtunuwu AL, Jeanette IC, Rampengan TH, Rampengan NH, Kosim S (2008). Efektivitas pemeriksaan prokalsitonin sebagai tanda dini sepsis pada anak. Sari Pediatri. 9(5):319-22. https://dx.doi.org/10.14238/sp9.5.2008.31922.

Schelonka RL, Chai MK, Yoder BA, Hensley D,Brockett RM, Ascher DP (1996). Volume of bloodrequired to detect common neonatal pathogens. J Pediatr. 129(2):275-8. https://doi.org/10.1016/soo22-3476(96)70254-8.

Stoll BJ, Shane AL (2016). Infection of the neonatal infant. Dalam: Kliegman RM, Stanton BF, Schor NF, St. Geme III JW, Behrman RE, penyunting. Nelson textbook of pediatrics. Edisi ke-20. Philadelphia: Elsevier.

Utomo MT (2010). Risk factors of neonatal sepsis: A preliminary study in dr. Soetomo hospital. Indones $\mathrm{J}$ Trop Infect Dis. 1(1): 23-6. http://dx.doi.org/10.20473/ijtid.vii1.3718.

Yu V, Monintja H (1997). Infeksi sistemik pada neonatus. Dalam: Yu V, Monintja H. editor. Beberapa masalah perawatan intensif neonatus; edisi pertama. Jakarta: Balai Penerbit FK UI.

Zahorec R (2001). Ratio of neutrophil to lymphocytecounts - rapid and simple parameter of systemicinflammation and stress in critically ill. Bratisl Med J. 102(1): 5-14. https://pubmed.ncbi.nlm.nih.gov/11723675/. 